\title{
How rare is rare? Quantifying and assessing the rarity of the bush dog Speothos venaticus across the Amazon and other biomes
}

\author{
Tadeu G. De Oliveira, Fernanda Michalsit, André L. M. Botelho \\ Lincoln J. Michalsit, Armando M. Calouro and Arnaud L. J. Desbiez
}

\begin{abstract}
The bush dog Speothos venaticus is a mediumsized Neotropical canid. It is considered to be rare and its biology and population parameters are still poorly understood. The Amazon is one of the main strongholds of this species and is important for maintaining viable populations, as the region still holds extensive tracts of pristine habitat. We gathered field data from camera-trap studies throughout the Brazilian Amazon to estimate the relative abundance of the species and gain an understanding of its rarity, and how this compares with estimates from other vegetative formations and for sympatric hypercarnivores. We focused on three pristine or partially disturbed sites and one fragmented site. The estimated relative abundance of the species was 0.060-0.185 individuals per 100 trap-days, confirming that the species is rare. The bush dog's abundance in the Amazon is equivalent to that in all other areas outside the Basin. The mean group size recorded was c. 2.5 individuals. There were no differences in group sizes between forests in the Amazon and in other regions of Central America; however, there were significant differences between forests and open habitats. A combination of competition/predation, habitat structure/integrity, and disease may be acting synergistically in determining the abundance and rarity of bush dogs.
\end{abstract}

TAdeu G. DE Oliveira* (Corresponding author) Departamento de Biologia, Universidade Estadual do Maranhão, Cidade Universitária Paulo VI - Caixa Postal 09, São Luís, Maranhão, 65055-000, Brazil. E-mail tadeu4@yahoo.com

Fernanda Michalski† Instituto Pró-Carnívoros, Atibaia, São Paulo, Brazil

André L. M. Botelho $\$$ Mestrado em Ecologia e Manejo de Recursos Naturais, Campus Universitário Rodovia, Rio Branco, Acre, Brazil

LinCOLn J. Michalski Faculdade de Itaituba, Itaituba, Pará, Brazil

Armando M. Calouro Universidade Federal do Acre, Centro de Ciências Biológicas e da Natureza, Campus Universitário-Rodovia, Rio Branco, Acre, Brazil

Arnaud L. J. Desbiez Royal Zoological Society of Scotland, Murrayfield, Edinburgh, UK

*Also at: Instituto Pró-Carnívoros, Parque Edmundo Zanoni, Atibaia, São Paulo, Brazil

†Also at: Laboratório de Ecologia e Conservação de Vertebrados, Universidade Federal do Amapá, Macapá, Amapá, Brazil

¥Also at: Instituto Federal de Educação, Ciência e Tecnologia do Acre. Campus Avançado Baixada do Sol, Rio Branco, Acre, Brazil

Received 24 January 2016. Revision requested 1 April 2016.

Accepted 22 June 2016. First published online 28 October 2016.
Keywords Amazon, bush dog, camera trap, conservation, group size, rarity, relative abundance, Speothos venaticus

To view supplementary material for this article, please visit https://doi.org/10.1017/So030605316000624

\section{Introduction}

The bush dog Speothos venaticus is a medium-sized (c. $6 \mathrm{~kg}$ ) Neotropical canid that lives in packs. The species' biology and population characteristics are poorly understood, and it is one of the least known carnivores in South America (Eisenberg \& Redford, 1999; Zuercher et al., 2004; DeMatteo \& Loiselle, 2008). Most information available on the species in Brazil comes from opportunistic observations (e.g. Peres, 1991; Silveira et al., 1998; Rocha et al., 2015; Michalski et al., 2015a), and it has only recently become the subject of longer-term studies (Lima et al., 2009, 2012, 2015).

The bush dog is recognized as being a rare carnivore (Zuercher et al., 2004; Oliveira, 2009; DeMatteo et al., 2011), and is categorized as Near Threatened on the IUCN Red List (DeMatteo et al., 2011) and Vulnerable in Brazil (Jorge et al., 2013). The Amazon Basin represents the species' main geographical range and is important for its long-term conservation (e.g. Zuercher et al., 2004; Oliveira, 2009). Currently, the Amazon has sufficient suitable habitat to maintain a genetically viable population of bush dogs (Oliveira, 2009).

The Amazon Basin is the largest tract of lowland rainforest, although many areas are under pressure from ongoing habitat loss and fragmentation as a result of human encroachment and development activities, especially along the so-called deforestation arc (Nogueira et al., 2015; Silva et al., 2015). To date, $18.8 \%$ of the original forest cover has been lost in the Brazilian Amazon alone (INPE, 2015) and further decline is predicted (e.g. a reduction to $53 \%$ of the original cover by 2050; Soares-Filho et al., 2006). The Amazon provides a safe haven for species that range within its boundaries (Rodrigues \& Oliveira, 2006), by a combination of extensive tracts of primary forest and a network of protected areas. However, given the current rate of deforestation and the number of existing and proposed hydroelectric dams (Tundisi et al., 2014; INPE, 2015) there is 
likely to be a major shift in the ecological landscape towards many isolated and fragmented habitats; for example, $>10$ million ha of forest are expected to be flooded as a result of the construction of hydroelectric dams (Fearnside, 2006), representing $2 \%$ of the total area of the Brazilian Amazon (FAO, 2005), which will contribute directly to widespread extinction of vertebrates (Benchimol \& Peres, 2015).

The detection and study of cryptic or elusive species has become easier and more reliable with the advent of camera trapping. Although the technique has drawbacks for certain species, such as arboreal or very small species, it has been utilized effectively to study several mammalian carnivores and has proved a reliable source of data for estimating relative abundance and population density (Carbone et al., 2001; O'Brien et al., 2003; O'Connell et al., 2011; Oliveira, 2011; Kasper et al., 2015). Although the rarity of bush dogs is widely acknowledged, there is no specific quantitative measure of abundance, nor has the abundance of bush dogs been compared with that of other sympatric hypercarnivores. The apparent rarity and distribution of this canid could be a product of competitive interactions with the puma Puma concolor, jaguar Panthera onca, and possibly ocelot Leopardus pardalis (Oliveira \& Pereira, 2014), as they share similar prey species (Oliveira, 2002; Zuercher et al., 2005; Lima et al., 2009; Oliveira et al., 2010). To address these issues we estimated the relative abundance of bush dogs in the Brazilian Amazon and compared it with those in other biomes and potential sympatric competitors/predators to assess the long-term conservation and persistence prospects of the species in this area.

\section{Study area}

The study focused on four sites in the south-west, central, south-central, and north-east of the Brazilian Amazon (Fig. 1). Three of these were mostly pristine (with slight disturbance; i.e. $<5 \%$ alteration by human activity, such as fire or logging) and one was fragmented. The study site at Alto Tarauacá Extractive Reserve, in the south-west, is in an area of open and closed rainforest with alluvial seasonally flooded forest and some degree of disturbance related to the latex extraction industry. The sites surveyed in the Reserve included areas where subsistence hunting had low and high impact (Botelho, 2013). The mid-Tapajós/ Amazonia National Park area in central Amazonia is characterized by a humid equatorial climate and hilly terrain with a mosaic of rainforest vegetation types. We used study areas both within and outside the park. The area is dominated by tall terra firme forest $(15-30 \mathrm{~m})$ interspersed by areas of lower forest and lianas $(10-15 \mathrm{~m})$. There is also an area of seasonally flooded riverine forest (igapó) occupying a narrow strip along the banks of the Tapajós River and its tributaries (George et al., 1988). The Amapá National Forest, in the north-east, is a sustainable-use area comprising continuous tropical rainforest vegetation, predominantly never-flooded terra firme forest, with some areas of flooded forest, bamboo and rocky outcrops (Michalski et al., 2015b). The Alta Floresta site is located along the deforestation arc of the Amazon and includes terra firme forest fragments of varying sizes, shapes and degrees of connectivity (Michalski et al., 2008).

\section{Methods}

\section{Defining rarity}

A rare species is one that is uncommon, scarce or encountered infrequently (Gaston, 1994). For the purpose of this study we define a rare species as one for which the number of camera-trap records is low, which is an inherent reflection of low density and small population size (Rabinowitz, 1981). This definition has been used in other studies of mammals (Cofré \& Marquet, 1999; Yu \& Dobson, 2000; Harcourt et al., 2002). We assessed camera-trap data (photographic records) from our study sites (Fig. 1) and for several uncommon and elusive species in the Neotropics (e.g. Martins et al., 2007; Tobler et al., 2008; Negrões et al., 2011; Pimenta, 2012; Botelho, 2013; Oliveira et al., 2014; Borges et al., 2015). Difficult-to-detect species such as the short-eared dog Atelocynus microtis, giant armadillo Priodontes maximus and giant anteater Myrmecophaga tridactyla were all recorded at rates of no more than 0.300 records per 100 trap-days. Thus, we considered species with $<0.300$ records per 100 trap-days to be rare.

\section{Bush dog abundance}

The location and arrangement of cameras was targeted towards mammalian carnivores. All cameras were spaced $0.5^{-1} \mathrm{~km}$ apart and typically positioned at $20-30 \mathrm{~cm}$ height along forest trails, riparian forest/stream banks, and at other sites where carnivores were likely to be detected. The protocol used for camera placement was based on the objective of gathering data on the abundance of carnivores and other mammals, and cameras were placed at optimum distances from the focal area to capture all mammals, and particularly bush dogs (mean shoulder height $25-30 \mathrm{~cm}$; Zuercher et al., 2004). This protocol was also followed to capture data on smaller $\left(<_{1} \mathrm{~kg}\right)$ mammals, such as small rodents and marsupials. Thus, we predicted the camera-trap sampling protocol would provide a robust representation of how common or rare carnivores were in these areas. As bush dogs are gregarious, we considered the total number of individuals captured on video or in photographic records to represent 


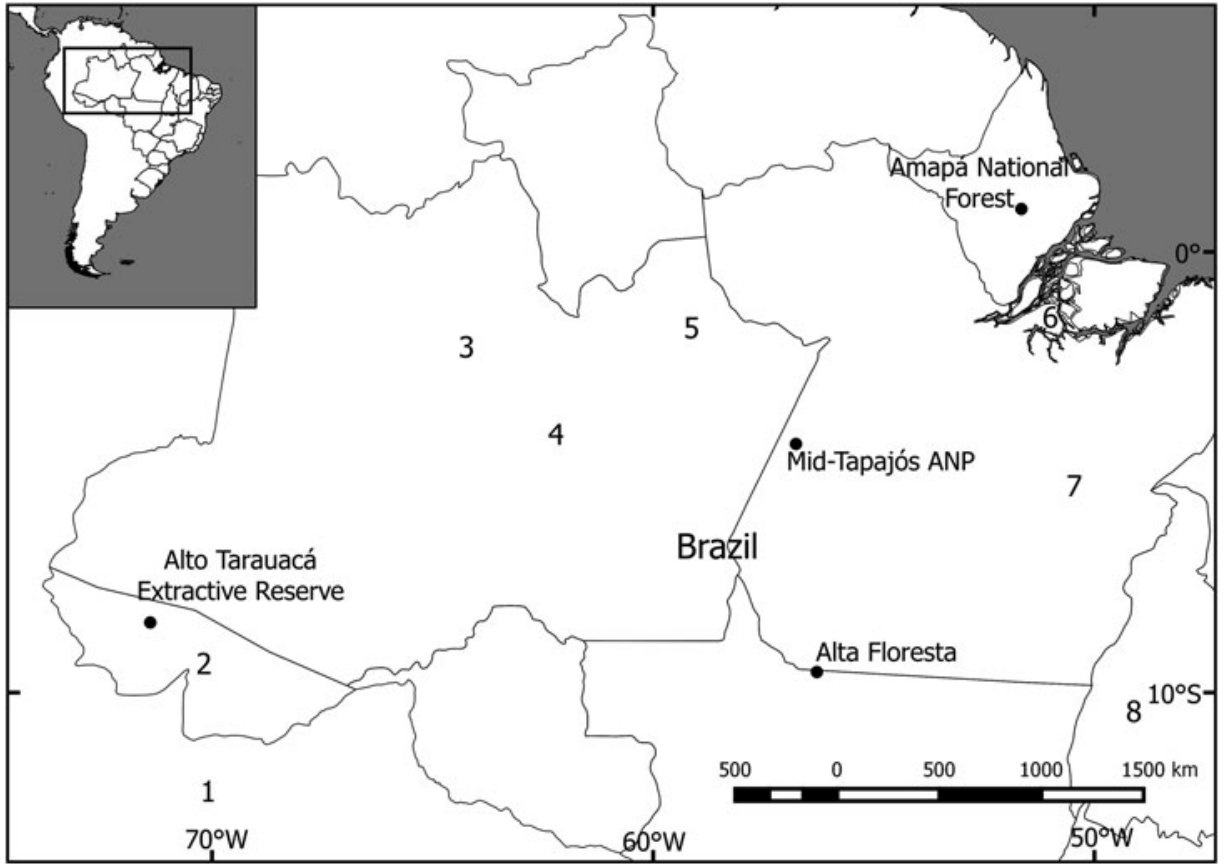

FIG. 1 Locations of the four study sites in the Amazon Basin where camera-trap surveys of the bush dog Speothos venaticus were conducted. Other camera-trap studies have been conducted at (1) Los Amigos Conservation Concession, Peru (Tobler et al., 2008), (2) Chandless State Park (Borges et al., 2015), (3) Amanã Sustainable Development Reserve (Rocha et al., 2015), (4) Piagaçu-Purus Sustainable Development Reserve (Pimenta, 2012), (5) Balbina Hydroelectric Dam (Benchimol \& Peres, 2015), (6) Caxiuanã National Forest (Martins et al., 2007), (7) Carajás National Forest (Bergallo et al., 2012), and (8) Cantão State Park (Negrões et al., 2011). relative abundance, reported as individuals per 100 trapdays. Consecutive photographic records of the same species were defined as independent occurrences if the individual(s) could be distinguished unambiguously or if the interval between records was $>30$ minutes (O'Brien et al., 2003). Bush dog group size was determined from the number of individuals recorded on camera or observed by researchers at the study sites during fieldwork. We assessed bush dog abundance in relation to the abundance of other sympatric hypercarnivores and the bush dog's main prey species, agouti Dasyprocta spp., paca Cuniculus paca and armadillo Dasypus spp. (Zuercher et al., 2004, 2005; Lima et al., 2009).

\section{Analytical procedures}

We present data as mean \pm standard deviation per sampling unit. We conducted normality tests to determine whether to use parametric or non-parametric statistics. To compare the abundance of bush dogs with that of their potential intraguild predators or competitors we used ANOVA on ranks, and Tukey's test for all pairwise multiple comparisons. We used ANOVA to compare bush dog group size among various vegetative formations, and the Holm-Sidak method for all pairwise multiple comparisons. We applied $t$-tests to compare bush dog abundance in the Amazon with all other areas in the species' range as well as abundance in fragmented and non-fragmented sites. We used a MannWhitney rank sum test to compare group size from cameratrap data and visual observations, and conducted regression analyses to determine the relationship between bush dog abundance and number of records with trap effort. The significance level was considered to be $\alpha=0.05$.

\section{Results}

\section{Rarity}

Trapping effort at our four study sites was 15,888 trap-days in total, which yielded a mean relative abundance of $0.117 \pm$ SD 0.052 bush dogs per 100 trap-days (range 0.060-0.185; Table 1). In pristine areas mean abundance was $0.136 \pm \mathrm{SD}$ 0.067 individuals per 100 trap-days, more than double that found at the fragmented Alta Floresta site (0.06o individuals per 100 trap-days). The species' rarity was confirmed by a lack of records in several other similar camera-trap studies across the Amazon, which accounted for an additional 40,949 trap-days (Table 2). Thus, considering the other sites where the focal species was observed (Table 2), the relative abundance of bush dogs in the Amazon was estimated to be $0.013-0.185$ individuals per 100 trap-days (mean $0.107 \pm \mathrm{SD} 0.064$; Negrões et al., 2011; Bergallo et al., 2012; Rocha et al., 2015; this study). The mean abundance in fragmented and non-fragmented areas across the Amazon Basin was 0.060 and $0.117 \pm$ SD 0.067 individuals per 100 trap-days, respectively. The mean for all cameratrap sites evaluated in the Amazon (including non-detection sites) was $0.058 \pm \mathrm{SD} 0.072$ individuals per 100 trap-days (range O-0.185; Martins et al., 2007; Tobler et al., 2008; Negrões et al., 2011; Pimenta, 2012; Benchimol \& Peres, 2015; Borges et al., 2015; Rocha et al., 2015; this study). Bush dog abundance in the Amazon was equivalent to 


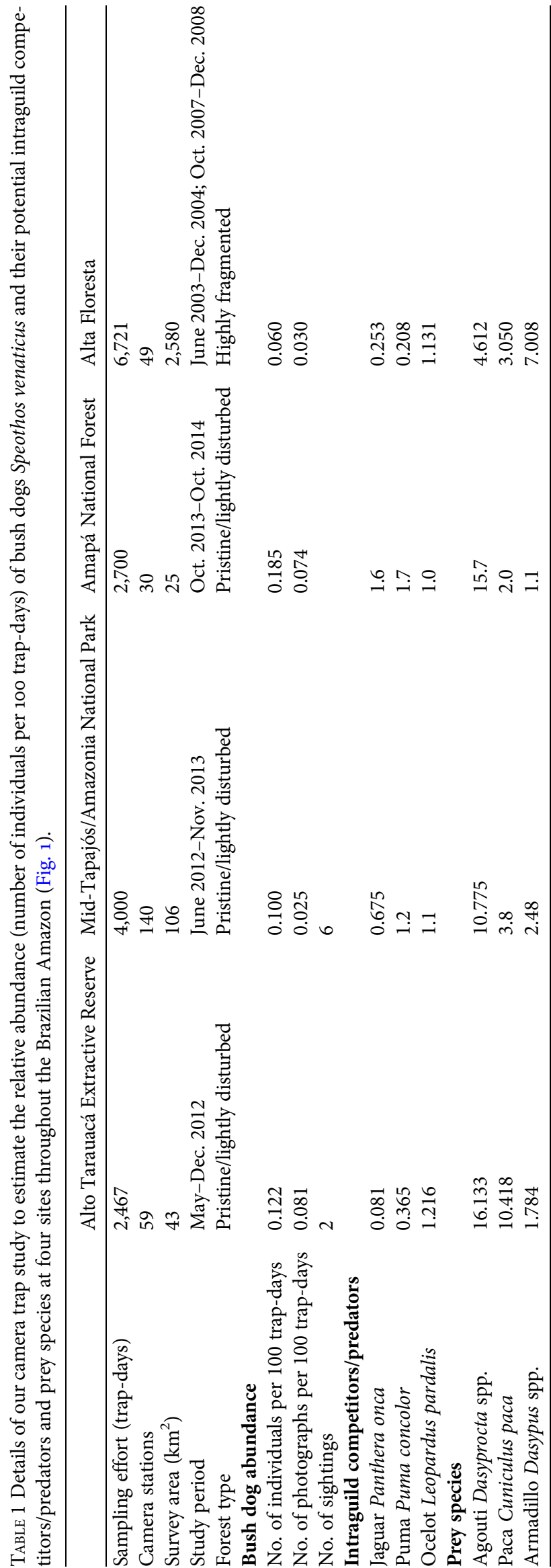

that in all other areas outside the Basin (mean $0.092 \pm \mathrm{SD}$ 0.061 individuals per 100 trap-days; $t=0.460, \mathrm{df}=12$, $\mathrm{P}=0.654$; Table 2). Additionally, no difference in abundance was found when comparing fragmented/disturbed and non-fragmented areas at any of the study sites $(t=1.351$, $\mathrm{df}=12, \mathrm{P}=0.202)$. As abundance was equivalent across all vegetation formations, we conducted regression analyses of bush dog abundance against camera-trap effort across all vegetation types. The expected relative abundance in relation to camera-trap effort was determined as follows: bush dog abundance $=0.130-\left(0.00000577^{\text {effort }}\right) \quad(r=0.557$, $\left.R^{2}=0.311, F_{1,12}=5.409, \mathrm{P}=0.038\right)$. Considering the number of records, we expected the following: bush dog photographic records $=1.240+\left(0.000137^{\text {effort }}\right)\left(r=0.6777, R^{2}=0.458\right.$, $\left.F_{1,12}=10.160, \mathrm{P}=0.008\right)$.

\section{Group size and activity}

All photographic records and some of the visual observations of bush dogs were from terra firme forest. Bush dogs were mostly recorded along trails (Plate 1) but were also sighted at road crossings, on stream banks and in igapó (flooded forest). The majority of both visual $(\mathrm{n}=8,100 \%)$ and cameratrap $(n=7,71.4 \%)$ records occurred during the day. There was no significant difference between group sizes estimated from camera-trap and visual records $(T=56.00, P=1.00$; Fig. 2). We found no significant differences between sizes of bush dog groups in Amazonian forests and in Central America $(T=286.5, \mathrm{P}=0.393$; Table 3). However, there were significant differences between forested environments and open formations of the Pantanal floodplains and savannahs $\left(F_{3,67}=3.397, \mathrm{P}=0.023\right)$.

\section{Species interactions}

The mean relative abundances of jaguars, pumas and ocelots in the study areas were $0.652 \pm$ SD $0.679,0.868 \pm$ SD 0.705 and 1.112 \pm SD 0.089 , respectively (Table 1; Supplementary Table $S_{1}$ ). All of these species, which are potential intraguild competitors or predators of the bush dog, were significantly more abundant than the bush $\operatorname{dog}(H=14.623, \mathrm{df}=3$, $\mathrm{P}=0.002$ ). Pairwise comparisons of relative abundances between hypercarnivores and bush dogs were also significantly different $(\mathrm{P}<0.05)$. In addition, relative abundances of the main prey species of the bush dog were relatively high at the four study sites (Table 1).

\section{Discussion}

\section{Bush dog rarity}

The relative abundances of bush dogs in the four study areas were low, corroborating previous observations and 
TABLE 2 Relative abundance of bush dogs recorded in camera-trap studies in major vegetation formations of the Amazon and Atlantic rainforests, the Pantanal floodplains and savannahs in Brazil, and the Central American forests in Panama, with sampling effort, no. of individuals per 100 trap days, habitat integrity, and data source.

\begin{tabular}{|c|c|c|c|c|c|}
\hline Site & $\begin{array}{l}\text { Sampling } \\
\text { effort (days) }\end{array}$ & $\begin{array}{l}\text { Individuals per } \\
100 \text { trap-days }\end{array}$ & $\begin{array}{l}\text { Photographs per } \\
100 \text { trap-days }\end{array}$ & Habitat integrity & Source \\
\hline \multicolumn{6}{|l|}{ Amazon (rainforest) } \\
\hline Alto Tarauacá Extractive Reserve & 2,467 & 0.122 & 0.081 & Pristine/lightly disturbed & This study \\
\hline $\begin{array}{l}\text { Mid-Tapajós/Amazonia National } \\
\text { Park }\end{array}$ & 4,000 & 0.100 & 0.025 & Pristine/lightly disturbed & This study \\
\hline Amapá National Forest & 2,700 & 0.185 & 0.074 & Pristine/lightly disturbed & This study \\
\hline Alta Floresta & 6,721 & 0.060 & 0.030 & Highly fragmented & This study \\
\hline $\begin{array}{l}\text { Amanã Sustainable Development } \\
\text { Reserve (Amazonas, Brazil) }\end{array}$ & 4,894 & 0.163 & 0.061 & Pristine/lightly disturbed & Rocha et al. (2015) \\
\hline $\begin{array}{l}\text { Carajás National Forest (Pará, } \\
\text { Brazil) }\end{array}$ & 3,572 & $\begin{array}{l}\text { Data } \\
\text { unavailable }\end{array}$ & 0.084 & Pristine/lightly disturbed & Bergallo et al. (2012) \\
\hline $\begin{array}{l}\text { Cantão State Park (Tocantins, } \\
\text { Brazil) }\end{array}$ & 7,929 & 0.013 & 0.013 & Pristine/lightly disturbed & Negrões et al. (2011) \\
\hline $\begin{array}{l}\text { Caxiuanã National Forest (Pará, } \\
\text { Brazil) }\end{array}$ & 2,838 & * & * & Pristine/lightly disturbed & Martins et al. (2007) \\
\hline $\begin{array}{l}\text { Chandless State Park (Acre, } \\
\text { Brazil) }\end{array}$ & 3,213 & * & * & Pristine/lightly disturbed & Borges et al. (2015) \\
\hline $\begin{array}{l}\text { Piagaçu-Purus Sustainable Use } \\
\text { Reserve (Amazonas, Brazil) }\end{array}$ & 3,743 & * & * & Pristine/lightly disturbed & Pimenta (2012) \\
\hline $\begin{array}{l}\text { Balbina Hydroelectric Dam } \\
\text { (Amazonas, Brazil) }\end{array}$ & 12,420 & * & * & Highly fragmented & $\begin{array}{l}\text { Benchimol \& Peres } \\
\text { (2015) }\end{array}$ \\
\hline $\begin{array}{l}\text { Los Amigos Conservation } \\
\text { Concession (Peru) }\end{array}$ & 2,340 & * & * & Pristine/lightly disturbed & Tobler et al. (2008) \\
\hline \multicolumn{6}{|l|}{ Atlantic Forest } \\
\hline $\begin{array}{l}\text { Carlos Botelho State Park (São } \\
\text { Paulo, Brazil) }\end{array}$ & 4,818 & 0.042 & 0.021 & Pristine/lightly disturbed & Beisiegel (2009) \\
\hline $\begin{array}{l}\text { Natural Reserves complex } \\
\text { (Paraná, Brazil) }\end{array}$ & 4,112 & 0.097 & 0.073 & $\begin{array}{l}\text { Lightly disturbed but } \\
\text { with fragments }\end{array}$ & $\begin{array}{l}\text { Fusco-Costa \& } \\
\text { Ingberman (2013) }\end{array}$ \\
\hline \multicolumn{6}{|l|}{ Pantanal floodplains/forest mosaic } \\
\hline $\begin{array}{l}\text { Nhumirim Ranch (Mato Grosso } \\
\text { do Sul, Brazil) }\end{array}$ & 2,238 & 0.179 & 0.045 & $\begin{array}{l}\text { Lightly-moderately } \\
\text { disturbed }\end{array}$ & Bianchi (2009) \\
\hline \multicolumn{6}{|l|}{ Cerrado (savannah) } \\
\hline $\begin{array}{l}\text { Veredas do Peruaçu State Park } \\
\text { (Minas Gerais, Brazil) }\end{array}$ & 6,000 & 0.017 & 0.017 & $\begin{array}{l}\text { Secondary savannah } \\
\text { with old Eucalyptus } \\
\text { plantation }\end{array}$ & Ferreira et al. (2015) \\
\hline \multicolumn{6}{|l|}{ Central American forests (Panama) } \\
\hline Pirre & 3,119 & 0.160 & 0.096 & Pristine/lightly disturbed & Meyer et al. (2015) \\
\hline Nusagandi & 830 & 0.120 & 0.120 & Pristine/lightly disturbed & Meyer et al. (2015) \\
\hline Donoso & 24,641 & 0.024 & 0.020 & Pristine/lightly disturbed & Meyer et al. (2015) \\
\hline Santa Fé & 3,165 & 0.095 & 0.063 & Pristine/lightly disturbed & Meyer et al. (2015) \\
\hline
\end{tabular}

* Species present but not detected by camera traps

conclusions that the species is rare (e.g. Zuercher et al., 2004; Oliveira, 2009; DeMatteo et al., 2011; Jorge et al., 2013). Although the abundance estimated from camera-trap records at the mid-Tapajós/Amazonia National Park site was lower compared to the other undisturbed areas, the number of visual records at this site was higher than at the other sites. Thus, relative abundance was similar across the study sites, except for the fragmented Alta Floresta area, where it was approximately half that at the other sites. Even with the limited number of records of the bush dog, it is clear that habitat fragmentation is a major conservation issue for this species. Previous studies of the species based on radio tracking have showed a trend of increasing home range with increasing degree of fragmentation of habitat (Lima et al., 2012, 2015; E. Lima, pers. comm.). We found a similar trend at our sites, with higher relative abundances of bush dogs in pristine or only slightly disturbed areas compared with fragmented areas. However, we found no differences when comparing camera-trap records from fragmented/disturbed and non-fragmented areas at any of the study sites. Given the generally low number of records of the species, caution is warranted regarding this issue. 


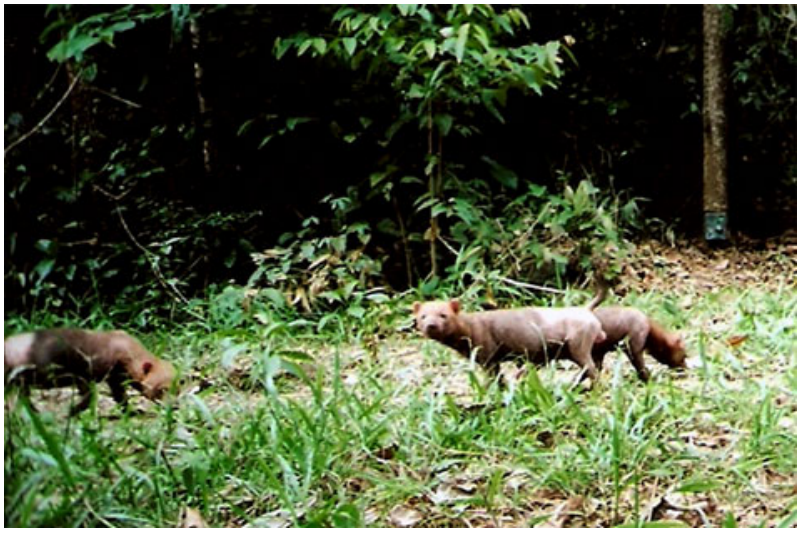

Plate 1 A bush dog Speothos venaticus pack at the disturbed and fragmented study site of Alta Floresta, Brazil (Fig. 1). Photograph by Fernanda Michalski.

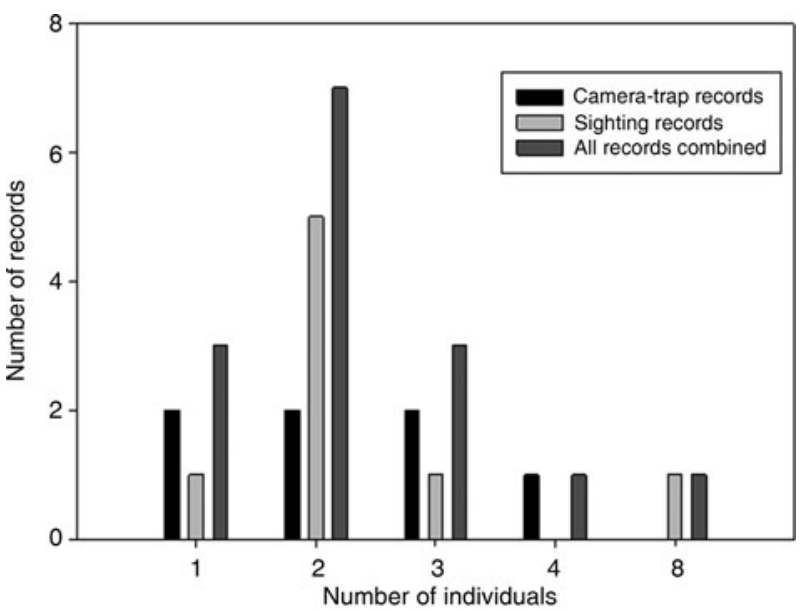

FIG. 2 The total number of bush dogs recorded by camera traps, sightings, and both methods combined, at the four study sites combined (Alto Tarauacá Extractive Reserve, Mid-Tapajós/ Amazonia National Park, Amapá National Forest and Alta Floresta; Fig. 1).

The inherent rarity of bush dogs was also highlighted by the fact that despite a large sampling effort $(2,340-12,420$ trap-days) the species was not recorded in $42 \%$ (5 of 12) of other systematic and robust camera-trap studies across the Amazon (Martins et al., 2007; Tobler et al., 2008; Pimenta, 2012; Benchimol \& Peres, 2015; Borges et al., 2015), most of which were conducted in areas with good habitat integrity. Nevertheless, it is important to highlight that absence of detection by camera-trapping does not prove that the species is absent in an area, only that the low numbers make it difficult to detect. It has been shown that the use of detection dogs is more accurate for locating this rare canid (DeMatteo et al., 2009).

Relative abundance estimates were from areas where bush dogs were considered to be relatively common (based on visual and/or other evidence). As such, this species is rare even when recorded in greater numbers (Bianchi,
2009; Meyer et al., 2015; Rocha et al., 2015; this study). Of all the carnivores that occur in the Amazon Basin only the socalled phantom species, the Amazon weasel Mustela africana and the northern tiger cat Leopardus tigrinus, may be rarer than the bush dog (Oliveira et al., 2013; Rodrigues, 2013).

This general pattern of rarity observed for the bush dog is not restricted to the Amazon Basin but is characteristic of the species throughout its range. Abundance estimates from the Amazon are similar to those from the Atlantic and Central American forests and the Pantanal floodplains and savannahs. Thus, the species is rare in all its habitats, irrespective of the area, biome or method of detection (camera trap, radio telemetry, detection dogs). This rarity is probably related to the species' inherently low population density, large home range and secretive behaviour (Zuercher et al., 2004; Beisiegel, 2009; DeMatteo et al., 2009; Lima et al., 2012, 2015; Fusco-Costa \& Ingberman, 2013; Ferreira et al., 2015; this study).

Camera-trap records are considered to be a consistent and reliable means of estimating the relative abundance of cryptic mammals (Carbone et al., 2001; Goulart et al., 2009; Negrões et al., 2011), although a linear relationship between the rate of photographic records and true abundance is assumed, as is a constant detection probability across space and time (O'Connell et al., 2011). Thus, it is possible that low abundance estimates reflect low detectability (Lima et al., 2012; Ferreira et al., 2015), in which case alternative methods, such as detection dogs, may be more costefficient for detecting rare species, including the bush dog (Long et al., 2007; DeMatteo et al., 2009). However, detection dogs may not be appropriate for population assessment of all species or in all areas, especially as there are no data on the use of dogs to detect Neotropical carnivores with which to make comparisons. Nevertheless, camera-trapping studies of carnivores, even rare ones, have proven to be effective for detecting and estimating abundance when compared to other techniques, such as telemetry, especially when trapping effort is high (e.g. > 2,00o trap-days; Soisalo \& Cavalcanti, 2006; T.G. Oliveira, 2011, unpubl. data; L.P. Meira et al., unpubl. data; this study). Additionally, bush dog behaviour in the study areas and elsewhere did not suggest avoidance of camera traps or camera locations. The number of records from our study areas also supports this argument. We therefore concur with previous, similar studies and conclude that bush dogs are rare.

In this study we considered any estimates of abundance $<0.300$ individuals per 100 trap-days to be indicators of rarity. We are confident that this is an accurate indicator when compared to camera-trap records for other Neotropical carnivores and rare or uncommon Neotropical mammals that were accurately sampled using the same technique (e.g. Tobler et al., 2008; Negrões et al., 2011; Botelho, 2013; Oliveira et al., 2014; L.P. Meira et al., unpubl. data). 
TABLE 3 Group sizes of bush dogs recorded in various vegetation formations throughout the species' range.

\begin{tabular}{|c|c|c|c|c|}
\hline Area/formation & Mean \pm SD & Range & $\begin{array}{l}\text { No. of } \\
\text { observations }\end{array}$ & Source \\
\hline Amazon forest & & & & This study \\
\hline Camera trap & $2.286 \pm 1.113$ & $1-4$ & 7 & \\
\hline Sighting & $2.75 \pm 2.188$ & $1-8$ & 8 & \\
\hline Combined & $2.533 \pm 1.727$ & $1-8$ & 15 & \\
\hline Central American forests & $2.421 \pm 1.712$ & $1-8$ & 19 & Meyer et al. (2015) \\
\hline $\begin{array}{l}\text { Northern Pantanal floodplains/ } \\
\text { forest/pastureland mosaic }\end{array}$ & $2.75 \pm 1.07$ & $1-7$ & 24 & Lima et al. (2009) \\
\hline $\begin{array}{l}\text { Savannahs \& Pantanal } \\
\text { floodplains }\end{array}$ & $4.556 \pm 2.833$ & $1-10$ & 9 & $\begin{array}{l}\text { Silveira et al. (1998), Lima et al. (2012, 2015), Teribele et al. } \\
\text { (2012), Ferreira et al. (2015), M. Buonato (unpubl. data) }\end{array}$ \\
\hline
\end{tabular}

\section{Group size and activity}

All photographic records were from terra firme forest; however, we also recorded sightings and track records in other areas, including at highway crossings, on stream banks and in igapó. Lima et al. $(2012,2015)$ reported that radio-tracked groups of bush dogs did not utilize roads, whereas Fusco-Costa \& Ingberman (2013) observed that they did. In any case, at our study sites cameras were not placed along roads, only on narrow trails. Similar to Rocha et al. (2015), the majority of our records suggest that this canid is predominantly diurnal. However, in the savannahs of Mato Grosso state (Brazil) a radio-tracked pack showed higher levels of activity both early in the morning and at night (Lima et al., 2012).

Typical groups of bush dogs are estimated to comprise 2-12 individuals, and most observations suggest group sizes of 2-6 (Zuercher et al., 2004). Previous camera-trap studies of the bush dog recorded groups of 1-8 individuals (Beisiegel, 2009; Bianchi, 2009; Negrões et al., 2011; Fusco-Costa \& Ingberman, 2013; Meyer et al., 2015; Rocha et al., 2015), which is similar to our results. Mean group sizes recorded in the Amazon and Panamanian forests were c. 2.5 individuals (Meyer et al., 2015). In a Pantanal floodplain savannah/forest/pastureland mosaic the mean group size (2.75) was only slightly larger than in forested areas (Lima et al., 2009). However, limited data from other open habitats in seasonally flooded floodplains and savannahs suggest larger and significantly different group sizes than those in forested areas (Lima et al., 2012, 2015; Teribele et al., 2012; Ferreira et al., 2015; Meyer et al., 2015; this study). Differences in group size between savannahs and forests may reflect differences in the availability or accessibility of the bush dog's main prey species between these vegetative formations. The predominantly small group size may be explained in part by the more solitary behaviour of Neotropical hypercarnivores (Oliveira \& Pereira, 2014), with the formation of groups being related to the need to subdue larger prey in some habitats (Zuercher et al., 2004, 2005).

\section{Species interactions}

The abundance of bush dogs at the study sites was low, and up to 10 orders of magnitude lower compared to intraguild competitors and predators. However, the highest abundance estimates for large felids in the study area are for Amapá National Forest, where the highest abundance of bush dogs was also recorded. Conversely, in the Tarauacá Extractive Reserve, where bush dog abundance was almost as high as in Amapá, large felids were uncommon. Although this appears to be contradictory, we suggest that our data can neither confirm nor deny the existence of intraguild interactions, which have been demonstrated for smaller Neotropical felids (Oliveira et al., 2010; Oliveira, 2011). Negative impacts of dominant competitors on subordinate competitors include decreases in niche breadth, restriction of habitat to less favourable areas, changes in activity patterns, and localized extinction, in addition to being preyed upon. Thus, subordinates tend to have smaller population sizes than dominant competitors (e.g. Miquelle et al., 2005; St-Pierre et al., 2006; Saleni et al., 2007; Oliveira et al., 2010; Oliveira, 2011). Thus, bush dog rarity may be a result of competitive interactions with jaguars, pumas and perhaps ocelots, as they share a similar prey base (Oliveira, 2002; Zuercher et al., 2005; Lima et al., 2009; Oliveira et al., 2010; Oliveira \& Pereira, 2014). Predation by domestic dogs could also be a threat in some areas (Ferreira et al., 2015; E. Lima, pers. comm.).

Relative abundances of the bush dog's main prey items (i.e. agouti, paca and armadillo) were relatively high at all of our study sites. Although prey availability is a defining factor of carnivore abundance, we suggest it may not be the limiting factor determining inherent bush dog rarity, as this would not explain their low abundance at our study sites or elsewhere (Ferreira et al., 2015; this study).

\section{Conservation issues}

The expansion of hydroelectric energy projects in the Amazon Basin, where most of the viable populations of 
bush dogs occur, will continue and possibly accelerate in the future. Current estimates vary from 94 to 151 additional dam projects planned for Amazonia (Tundisi et al., 2014). This will introduce large-scale changes to the hydrological cycle, inland connectivity and ecosystem services, which will in turn affect the persistence and maintenance of several species populations. This future scenario for the Amazon Basin in Brazil is of particular concern (Soares-Filho et al., 2006). The population viability assessment conducted for Amazonia National Park showed a 50\% probability of extinction of the bush dog in $<100$ years if populations become isolated (Godoy et al., 2015). The overall scenario for this area is predicted to worsen as the population size and carrying capacity decrease as a result of the suppression of flooded riverine forest following the installation and operation of a hydroelectric dam (Godoy et al., 2015). Simulations indicate that isolation, which has already begun in some places (Nogueira et al., 2015; Silva et al., 2015), reduces the likelihood that even forest reserves of $>10,000 \mathrm{~km}^{2}$ would be adequate to maintain viable populations of bush dogs and to provide the conditions necessary for the long-term conservation of this rare canid.

\section{Conclusions}

Extensive tracts of undisturbed forest with low levels of human impact dominated the study areas, except for Alta Floresta, yet even in pristine areas the bush dog is naturally rare and threatened by predation and disease. Sarcoptic mange in particular is one of the main threats to the species in all Brazilian biomes (e.g. Jorge et al., 2013; Godoy et al., 2015). Disease can cause the loss of species from some areas for prolonged periods, as observed for short-eared dogs in Peru (Leite-Pitman \& Williams, 2011). Diseases affecting wild canids tend to be transmitted from domestic dogs, which are commonly brought into protected and unprotected forested areas by local and indigenous people (Leite-Pitman et al., 2003; Leite-Pitman \& Williams, 2011). However, it is unlikely that disease alone could pose a simultaneous threat across the entire range of the bush dog, or be the sole cause of its rarity. Rather, the inherent rarity of the bush dog (defined here as $<0.300$ individuals per 100 trap-days) appears to be attributable to a combination of competitive pressure and predation (intraguild or otherwise), habitat structure and integrity, and disease, acting synergistically (but not separately) to determine the abundance and degree of rarity in any particular area.

\section{Acknowledgements}

We thank CNEC WorleyParsons Engenharia S.A. and Eletrobras, who provided logistical and financial support for the fieldwork in the mid-Tapajós/Amazonia National
Park area. Fieldwork there depended on the assistance of many colleagues; we are especially indebted to Fábio Mazim, Gilberto Nascimento, Jean Pierre Santos, and José Bonifácio Soares. We thank Instituto Chico Mendes de Conservação da Biodiversidade and the Federal University of Amapá for logistical support at the Amapá National Forest study site, and the Programa de Pesquisa em Biodiversidade Biodiversity Monitoring Programme for providing the grid system used during field activities there. We thank Cremilson Marques, Érico Kauano and Sueli dos Santos for their assistance during the field work. The United Nations Development Programme (UNDP), Coordenação de Aperfeiçoamento de Pessoal de Nível Superior (CAPES) and Fundação de Tecnologia do Estado do Acre funded the work in Acre. Rosenil Oliveira and Cláudia Cunha provided field assistance in Acre. Fundação de Amparo à Pesquisa e ao Desenvolvimemto Científico e Tecnológico do Maranhão (FAPEMA) provided additional support. Nuno Negrões and several anonymous reviewers provided important and insightful comments.

\section{Author contributions}

TGO, FM, ALMB and LJM collected and analysed the data, and co-wrote the article with AMC and ALJD.

\section{References}

Beisiegel, B.M. (2009) First camera trap record of bush dogs in the state of São Paulo, Brazil. Canid News, 12.5, 1-5.

Benchimol, M. \& Peres, C.A. (2015) Widespread forest vertebrate extinctions induced by a mega hydroelectric dam in lowland Amazonia. PLoS ONE, 10(7), eo129818.

Bergallo, H.G., Carvalho, A.S., Reis, M.L. \& Costa, F.G. (2012) Mamíferos de médio e grande porte. In Fauna da Floresta Nacional de Carajás: estudos sobre vertebrados terrestres (eds F.D. Martins, A.F. Castillo, J. Campos, F.M. Hatano \& S.G. Rolim), pp. 180-195. Nitro Imagens, São Paulo, Brazil.

BIANCHI, R.C. (2009) Ecologia de mesocarnívoros em uma área no Pantanal Central. PhD thesis. Universidade Federal do Mato Grosso do Sul, Campo Grande, Brazil.

Borges, L.H.M., Calouro, A.M. \& de Sousa, J.R.D. (2015) Large and medium-sized mammals from Chandless State Park, Acre, Brazil. Mastozoología Neotropical, 22, 265-277.

Botelho, A.L.M. (2013) Caça de subsistência e os mamíferos da Resex do Alto Tarauacá, Acre. MSc thesis. Universidade Federal do Acre, Rio Branco, Brazil.

Carbone, C., Christie, S., Conforti, K., Coulson, T., Franklin, N., Ginsberg, J.R. et al. (2001) The use of photographic rates to estimate densities of tigers and other cryptic mammals. Animal Conservation, 4, 75-79.

Cofré, H. \& Marquet, P.A. (1999) Conservation status, rarity, and geographic priorities for conservation of Chilean mammals: an assessment. Biological Conservation, 88, 53-68.

DeMatteo, K.E. \& Loiselle, B.A. (2008) New data on the status and distribution of the bush dog (Speothos venaticus): evaluating its quality of protection and directing research efforts. Biological Conservation, 141, 2494-2505. 
DeMatteo, K., Michalski, F. \& Leite-Pitman, M.R.P. (2011) Speothos venaticus. The IUCN Red List of Threatened Species 2011: e.T20468A9203243. Http://dx.doi.org/10.2305/IUCN.UK.2011-2. RLTS.T20468A9203243.en [accessed 27 October 2015].

DeMatteo, K.E., Rinas, M.A., Sede, M.M., Davenport, B., Argüelles, C.F., Lovett, K. \& Parker, P.G. (2009) Detection dogs: an effective technique for bush dog surveys. The Journal of Wildlife Management, 73, 1436-1440.

Eisenberg, J.F. \& Redford, K.H. (1999) Mammals of the Neotropics. Volume 3. Ecuador, Peru, Bolivia, Brazil. University of Chicago Press, Chicago, USA.

FAO (2005) Computerized Data Gathering and Networking as a Control and Monitoring System for the Improvement of and Reporting on Forest Management in the Amazon: The Case of Brazil. Forest Management Working Papers, Working Paper 27. Forest Resources Development Service, Forest Resources Division, FAO, Rome, Italy.

Fearnside, P.M. (2006) Dams in the Amazon: Belo Monte and Brazil's hydroelectric development of the Xingu River Basin. Environmental Management, 38, 16-27.

Ferreira, G.B., Oliveira, M.J.R., De Paula, R.C., Rodrigues, F.H. G. \& CARMO, E.D.C. (2015) Regionally extinct species rediscovered the bush dog Speothos venaticus in Minas Gerais, south-eastern Brazil. Oryx, 49, 60-63.

Fusco-Costa, R. \& Ingberman, B. (2013) Records of the bush dog Speothos venaticus in a continuous remnant of coastal Atlantic Forest in southern Brazil. Oryx, 47, 105-108.

Gaston, K.J. (1994) Rarity. Chapman \& Hall, London, UK.

George, T.K., Marques, S.A., De Vivo, M., Branch, L.C., Gomes, N. \& Rodrigues, R. (1988) Levantamento de mamíferos do ParnaTapajós. Brasil Florestal, 63, 33-41.

Godoy, S., Desbiez, A.L.J. \& Miller, P. (eds) (2015) Bush Dog Population Viability Workshop. IUCN/SSC Conservation Breeding Specialist Group (CBSG), Atibaia, Brazil.

Goulart, F.V.B., Cáceres, N.C., Graipel, M.E., Tortato, M.A., Ghizoni, Jr, I.R. \& Oliveira-Santos, L.G.R. (2009) Habitat selection by large mammals in a southern Brazilian Atlantic Forest. Mammalian Biology, 74, 182-190.

Harcourt, A.H., Coppeto, S.A. \& Parks, S.A. (2002) Rarity, specialization and extinction in primates. Journal of Biogeography, 29, 445-456

INPE (2015) Levantamento das áreas desflorestadas da Amazônia Legal no período 1988-2015: resultados. Http:/www.obt.inpe.br/ prodes/prodes_1988_2015n.htm [accessed 17 January 2016].

Jorge, R.P.S., Beisiegel, B.M., Lima, E.S., Jorge, M.L.S.P., LeitePitman, M.R.P. \& Paula, R.C. (2013) Avaliação do estado de conservação do cachorro-vinagre Speothos venaticus (Lund, 1842) no Brasil. Biodiversidade Brasileira, 3, 179-190.

Kasper, C.B., Mazim, F.D., Soares, J.B.G. \& de Oliveira, T.G. (2015) Density estimates and conservation of Leopardus pardalis southernmost population of the Atlantic Forest. Iheringia, Série Zooologia, 105, 367-371.

Leite-Pitman, M.R.P., Nieto, F.V. \& Davenport, L. (2003) Amenaza de enfermedades epidémicas a la conservación de carnívoros silvestres en la Amazonía peruana. In Alto Purús: Biodiversidad, Conservación y Manejo (eds M.R.P. Leite Pitman, N.C.A. Pitman \& P.C. Alvarez), pp. 227-231. Center for Tropical Conservation and INRENA, Lima, Peru.

Leite-Pitman, M.R.P. \& Williams, R.S.R. (2011) Atelocynus microtis. The IUCN Red List of Threatened Species 2011: e.T6924A12814890. Http://dx.doi.org/10.2305/IUCN.UK.2011-2. RLTS.T6924A1281489o.en [accessed 27 October 2015].

Lima, E.S., DeMatteo, K.E., Jorge, R.S.P., Jorge, M.L.S.P., Dalponte, J.C., Lima, H.S. \& Klorfine, S.A. (2012) First telemetry study of bush dogs: home range, activity and habitat selection. Wildlife Research, 39, 512-519.

Lima, E.S., Jorge, R.S.P. \& Dalponte, J.C. (2009) Habitat use and diet of bush dogs, Speothos venaticus, in the Northern Pantanal, Mato Grosso, Brazil. Mammalia, 73, 13-19.

Lima, E.S., Jorge, M.L.S.P., Jorge, R.S.P. \& Morato, R.G. (2015) The bush dog Speothos venaticus: area requirement and habitat use in cultivated lands. Oryx, 49, 64-70.

Long, R.A., Donovan, T.M., Mackay, P., Zielinski, W.J. \& Buzas, J.S. (2007) Effectiveness of scat detection dogs for detecting forest carnivores. The Journal of Wildlife Management, 71, 2007-2017.

Martins, S.S., Sanderson, J.G. \& Silva-Júnior, J.S. (2007) Monitoring mammals in the Caxiuanã National Forest, Brazil-First results from the Tropical Ecology, Assessment and Monitoring (TEAM) program. Biodiversity and Conservation, 16, 857-870.

Meyer, N., Moreno, R., Valdes, S., Méndez-Carvajal, P., Brown, E. \& Ortega, J. (2015) New records of bush dog in Panama. Canid Biology \& Conservation, 18, 36-40.

Michalski, F., Peres, C.A. \& Lake, I.R. (2008) Deforestation dynamics in a fragmented region of southern Amazonia: evaluation and future scenarios. Environmental Conservation, 35, 93-103.

Michalski, L.J., de Oliveira, T.G. \& Michalski, F. (2015a) New record for bush dog in Amapá State, Eastern Brazilian Amazonia. Canid Biology \& Conservation, 18, 3-5

Michalski, L.J., Norris, D., de Oliveira, T.G. \& Michalski, F. (2015b) Ecological relationships of meso-scale distribution in 25 Neotropical vertebrate species. PLoS ONE, 10(5), eo126114.

Miquelle, D.G., Stephens, P.A., Smirnov, E.N., Goodrich, J.M., Zaumyslova, O.J. \& Myslenkov, A.E. (2005) Tigers and wolves in the Russian far east: competitive exclusion, functional redundancy, and conservation implications. In Large Carnivores and the Conservation of Biodiversity (eds J.C. Ray, K.H. Redford, R.S. Steneck \& J. Berger), pp. 179-207. Island Press, Washington, DC, USA.

Negrões, N., Revilla, E., Fonseca, C., Soares, A.M.V.M., Jácomo, A.T.A. \& Silveira, L. (2011) Private forest reserves can aid in preserving the community of medium and large-sized vertebrates in the Amazon arc of deforestation. Biodiversity and Conservation, 20, 505-518.

Nogueira, E.M., Yanai, A.M., Fonseca, F.O.R. \& Fearnside, P.M. (2015) Carbon stock loss from deforestation through 2013 in Brazilian Amazonia. Global Change Biology, 21, 1271-1292.

O’Brien, T.G., Kinnaird, M.F. \& Wibisono, H.T. (2003) Crouching tigers, hidden prey: Sumatran tiger and prey populations in a tropical forest landscape. Animal Conservation, 6, 131-139.

O’Connell, A.F., Nichols, J.D. \& Karanth, K.U. (eds) (2011) Camera Traps in Animal Ecology: Methods and Analyses. Springer, New York, USA.

Oliveira, T.G. (2002) Ecología comparativa de la alimentación del jaguar y del puma en el neotrópico. In El Jaguar en el Nuevo Milenio (eds R.A. Medellín, C. Equihua, C.L.B. Chetkiewicz, P.G. Crawshaw Jr., A. Rabinowitz, K.H. Redford et al.), pp. 265-288. Fondo de Cultura Económica/Universidad Nacional Autónoma de México/ Wildlife Conservation Society, Mexico City, Mexico.

Oliveira, T.G. (2009) Distribution, habitat utilization and conservation of the Vulnerable bush dog Speothos venaticus in northern Brazil. Oryx, 43, 247-253.

Oliveira, T.G. (2011) Ecologia e conservação de pequenos felinos no Brasil e suas implicações para o manejo. $\mathrm{PhD}$ thesis. Universidade Federal de Minas Gerais, Belo Horizonte, Brazil.

Oliveira, T.G. \& Pereira, J.A. (2014) Intraguild predation and interspecific killing as structuring forces of carnivoran communities in South America. Journal of Mammalian Evolution, 21, 427-436. 
Oliveira, T.G., Tortato, M.A., Almeida, L.B., Campos, C.B. \& Beisiegel, B.M. (2013) Avaliação do risco de extinção do gato-do-mato Leopardus tigrinus (Schreber, 1775) no Brasil. Biodiversidade Brasileira, 3, 56-65.

Oliveira, T.G., Tortato, M.A., Silveira, L., Kasper, C.B., Mazim, F.D., Lucherini, M., et al. (2010) Ocelot ecology and its effect on the small-felid guild in the lowland Neotropics. In Biology and Conservation of Wild Felids (eds D.W. Macdonald \& A.J. Loveridge), pp. 563-574. Oxford University Press, Oxford, UK.

Oliveira, T.G., Vieira, O.Q., Kasper, C.B., Trevelin, L.C. et al. (2014) Mastofauna. In Relatório de impacto ambiental: AHE São Luiz do Tapajós; Estudo de impacto ambiental, aproveitamento hidrelétrico São Luiz do Tapajós. Volume 13. pp. 1-10o. CNEC (Consórcio Nacional dos Engenheiros Consultores), São Paulo, Brazil.

Peres, C.A. (1991) Observations on hunting by small-eared dog (Atelocynus microtis) and bush dog (Speothos venaticus) in central-western Amazonia. Mammalia, 55, 635-639.

Pimenta, C.S. (2012) Uso do habitat e ocupação por carnívoros em uma Reserva de Uso Sustentável na Amazônia Central, Brasil. MSc thesis. Instituto Nacional de Pesquisa da Amazônia, Manaus, Brazil.

Rabinowitz, D. (1981) Seven forms of rarity. In The Biological Aspects of Rare Plant Conservation (ed. H. Synge), pp. 205-217. Wiley, New York, USA.

Rocha, D.G., Ramalho, E.E., Alvarenga, G.C., Gräbin, D.M. \& Magnusson, W.E. (2015) Records of the bush dog (Speothos venaticus) in Central Amazonia, Brazil. Journal of Mammalogy, 96, 1361-1364.

Rodrigues, L.A. (2013) Avaliação do risco de extinção da doninha-Amazônica Mustela africana (Desmarest, 1818) no Brasil. Biodiversidade Brasileira, 3, 191-194.

Rodrigues, F.H.G. \& Oliveira, T.G. (2006) Unidades de conservação e seu papel na conservação de carnívoros brasileiros. In Manejo e conservação de carnívoros neotropicais (eds R.G. Morato, F.H.G. Rodrigues, E. Eizirik, P.R. Mangini, F.C.C. Azevedo \& J. Marinho-Filho), pp. 97-110. Edições IBAMA, Brasília, Brazil.

Saleni, P., Gusset, M., Graf, J.A., Szykman, M., Alters, M. \& Somers, M.J. (2007) Refuges in time: temporal avoidance of interference competition in endangered wild dogs Lycaon pictus. Canid News, 10.2, 1-5.

Silva, M.E.S., Pereira, G. \& da Rocha, R.P. (2015) Local and remote climatic impacts due to land use degradation in the Amazon "Arc of Deforestation". Theoretical and Applied Climatology, 125, 609-623.

Silveira, L., Jасомо, A.T.A., Rodrigues, F.H.G. \& Diniz-Filho, J.A.F. (1998) Bush dogs (Speothos venaticus), in Emas National Park, Central Brazil. Mammalia, 62, 446-449.
Soares-Filho, B.S., Nepstad, D.C., Curran, L.M., Cerqueira, G.C., GarCiA, R.A., Ramos, C.A. et al. (2006) Modelling conservation in the Amazon basin. Nature, 440, 520-523.

Soisalo, M.K. \& Cavalcanti, S.M.C. (2006) Estimating the density of a jaguar population in the Brazilian Pantanal using camera-traps and capture-recapture sampling in combination with GPS radio-telemetry. Biological Conservation, 129, 487-496.

St-Pierre, C., Ouellet, J.P. \& Crête, M. (2006) Do competitive intraguild interactions affect space and habitat use by small carnivores in a forested landscape? Ecography, 29, 487-496.

Teribele, R., Concone, H.V.B., Godoi, M.N., Bianchi, R.C., Santos, J.C.C., Mauro, R.A. et al. (2012) New records for bush dog in Mato Grosso do Sul, Brazil. Canid News, 15, 1-4.

Tobler, M.W., Carrillo-Percastegui, S.E., Pitman, R.L., Mares, R. \& Powell, G. (2008) An evaluation of camera traps for inventorying large- and medium-sized terrestrial rainforest mammals. Animal Conservation, 11, 169-178.

Tundisi, J.G., Goldemberg, J., Matsumura-Tundisi, T. \& Saraiva, A.C.F. (2014) How many more dams in the Amazon? Energy Policy, 74, 703-708.

Yu, J. \& Dobson, F.S. (2000) Seven forms of rarity in mammals. Journal of Biogeography, 27, 131-139.

Zuercher, G.L., Gipson, P.S. \& Carillo, O. (2005) Diet and habitat associations of bush dogs Speothos venaticus in the Interior Atlantic Forest of eastern Paraguay. Oryx, 39, 86-89.

Zuercher, G.L., Swarmer, M., Silveira, L. \& Carrillo, O. (2004) Bush dog Speothos venaticus (Lund, 1842). In Canids: Foxes, Wolves, Jackals and Dogs: Status Survey and Conservation Action Plan (eds C. Sillero-Zubiri, M. Hoffmann \& D.W. Macdonald), pp. 76-8o. IUCN Gland, Switzerland, and Cambridge, UK.

\section{Biographical sketches}

Tadeu de Oliveira's main research interests are the ecology and conservation of Neotropical carnivores. FERnANDA Michalski's research interests are in conservation biology and the ecological consequences of habitat fragmentation on large and mid-sized vertebrates. ANDRE BOTELHO is a wildlife ecologist and is interested in the ecology and conservation of medium-to-large sized mammals. LiNCOLN MICHALSKI is a wildlife ecologist whose main research interests are in the ecology and conservation of mammals. ARMANDO CALOURO is interested in the effects of anthropogenic perturbations on mammals in the south-western Brazilian Amazon. ARna ud Desbiez's research focuses on sustainable use of natural resources and species conservation. 